\title{
Imagistic Analysis of Dental Adhesives Loaded with Nanoparticles Used on Teeth Sealing of Pits and Fissures with Resin Based Materials
}

\author{
ROXANA OANCEA ${ }^{1}$, CRISTIAN ZAHARIA ${ }^{1}$, ALIN-GABRIEL GABOR ${ }^{1}$, COSMIN SINESCU ${ }^{1}$, MARIUS MIOC ${ }^{2 *}$, \\ DELIA BERCEANU VADUVA²*, CATALIN PETRU SIMON ${ }^{1}$, VLAD SOCOLIUC ${ }^{3}$, MIHAI ROMINU ${ }^{1}$, MEDA-LAVINIA NEGRUTIU ${ }^{1}$ \\ IVictor Babes University of Medicine and Pharmacy, Faculty of Dental Medicine, 9 Revolutiei 1989 Blv., 300070, Timisoara, \\ Romania \\ 2 Victor Babes University of Medicine and Pharmacy, Faculty of Pharmacy, Department Of Pharmaceutical Chemistry, 2 Eftimie \\ Murgu Sq., RO-300041, Timisoara, Romania \\ ${ }^{3}$ Romanian Academy -Timisoara Branch, Center for Fundamental and Advanced Technical Research, Laboratory of Magnetic \\ Fluids, 24 Mihai Viteazu Av., 300223 Timisoara, Romania
}

\begin{abstract}
Recentassessments show an increase in the incidence of tooth decay. In addition to prophylactic treatments using fluoride and diet focused on low sugar consumption, application of sealing materials to the teeth surfaces is the best protection against the appearance of dental caries on both temporary and permanent teeth. Tooth sealing applied using conventional method, plus the application of adhesive systems can lead to noticeable results over time.An increased thickness of the adhesive layer may lead to microinfiltration and implicitly to a failure of the dental caries protection therapy.Loading the dental adhesive with magnetic nanoparticles and applying it to the surface of the teeth with the help of a the magnetic field attempts to reduce and uniformize the thickness of the adhesive layer, which can lead to a reduced decrease in the occurrence of dental caries under the sealing materials for pit and fissures on the occlusal surfaces.
\end{abstract}

Keywords: dental adhesive, nanoparticles, dental sealants, optical microscopy, dental adhesive thickness

Dental caries are still considered a condition that affects the quality of life and health of the affected person. One of the most importantmeasures for preventing caries, besides rigorous hygiene and the use of fluoride, can be considered sealing the pits and fissures on the surface of the teeth with dental sealants [1].

Even though the rhythm of dental caries is on a downward trend, some research has shown that nearly a quarter of preschool children experience carious lesions on temporary teeth [2].

An imbalance in the dynamics of the demineralization / remineralization process leads to the loss of minerals and implicitly to the appearance of the carious processes. Dental caries involve many protective and risk factors. Biological, behavioral and environmental factors can influence the severity of carious disease. Decreasing the $\mathrm{pH}$ of the bacterial plaque to 4 can lead to destruction of dental tissue over time, while the presence of fluoride in the dental biofilm is a protective factor for the teeth [3].

The most important risk in the appearance of dental caries is the presence of active demineralization areas on the proximal and occlusal teeth surfaces. This component is recognized to be the most important risk factor in tooth decay for all ages [4].

The presence on the dental surfaces of the active carious lesions may be an impediment to the use of resin-based sealantand glass ionomer sealant. Literature indicated that sealant efficiency is 100\% after 1 year application and $98 \%$ at 3 years and 8 months. If lesions on the occlusal surfaces of the teeth are without cavities (ICDAS 0-4), they can be sealed with dental sealants and can be evaluated with devices such as DIAGNOdent or QLF [5].

Dental materials used for pit and fissures sealing on dental surfaces are represented by resin-based sealants and glass ionomer sealants [6].
Resin sealants can be used to prevent tooth decay for both children and adolescents by applying protective materials to the occlusal surfaces of permanent molars [7].

Among the advantages of glassionomer sealants is the change in fluoride level in the oral cavity, which can lead to an increased rate of caries prevention. Over time, compared to resins based sealants, glassionomer sealants had a higher failure rate [8].

By mixing the benefits of the two groups of materials, the researchers developed fluoride-releasing compomers and modified resin ionomers [9-11].

To preventor to stop the progression of non-cavity carious lesions, resin based dental materials for pit and fissures, can be used with success $[12,13]$.

The disadvantages that can occur in the case of dental seals with resin based materials are the contraction during polymerization and the possibility of microinfiltration. These microinfiltrations will cause the occlusal barrier to break with saliva penetration and bacteria colonization, resulting dental caries [14].

The penetration ratio of the sealing material is not affected by the sealing material nor the enamel surface on which it is applied. The penetration ratio of the sealant is modified by the morphology of the surface to which it is applied, i.e., the Y-shaped fissures allow the smallest penetration of the sealing material, and the U-shaped fissures have the highest penetration ratio for the sealant [15].

Clinical retention of sealing materials has been significantly improved by applying to the dental surface of self-etch adhesives or those using the etch-and-rinse technique by pre-etched acid engraving of the enamel [16] .

\footnotetext{
*email: marius.mioc@umftro, Phone: 0756236715; deliaberceanu@yahoo.com, Phone: 0723211191
} 
The thickness of the adhesive layer applied to the tooth surface by conventional techniques for direct or indirect teeth restoration is between 0 and 500 microns $[17,18]$.

The purpose of this study is to analyze the thickness layer of dental adhesive (between the dental surface and the resin material used in sealing of the dental pits and fissures) loaded with magnetic nanoparticles and applied on the surface of the enamel using conventional technique and the aid of a magnetic field applied for $2 \mathrm{~min}$ and $5 \mathrm{~min}$.

\section{Experimental part}

In this study, 20 non-carious extracted teeth were used. All the pits and fissures were covered by dental sealants applied with conventional adhesive technique, the adhesive layer being analyzed by the optical microscopy.

The technique used to seal the pits and fissures of occlusal surfaces included the use of Guluma 2Bond dental adhesive manufactured by Kulzer (Germany), ASeal $F$ sealing material produced by Schulzer (Germany), 37\% phosphoric acid produced by Cerkamed (Poland) and single- $\mathrm{Fe}_{3} \mathrm{O}_{4}$ particles (fig.1.a.).

For 5 samples, the applied adhesive was not loaded with magnetic nanoparticles, being applied to the surface of the teeth by brushing, followed by air-blowing and lightcuring. For the other 15 samples, the dental adhesive was loaded with magnetic nanoparticles (fig.1.b.).

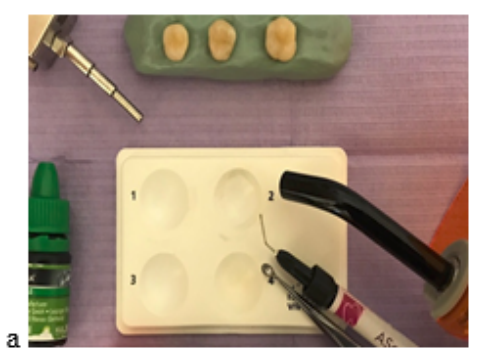

Fig.1. a) Armamentarium used in this study; b) Single core $\mathrm{Fe}_{3} \mathrm{O}_{4}$ particles mixed with dental adhesive

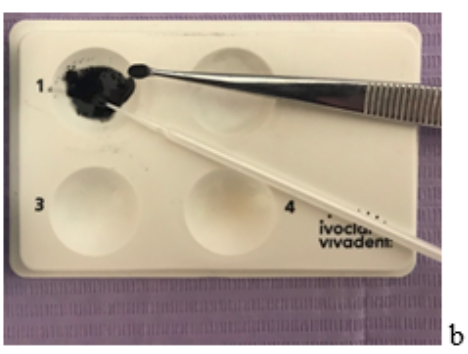

For all samples, demineralization of enamel surfaces with phosphoric acid was performed for $30 \mathrm{~s}$, followed by water jet washing and air-jet drying for $5 \mathrm{~s}$ (fig.2.a.). After demineralization with $37 \%$ phosphoric acid, the adhesive was applied to enamel surfaces (fig.2.b.).
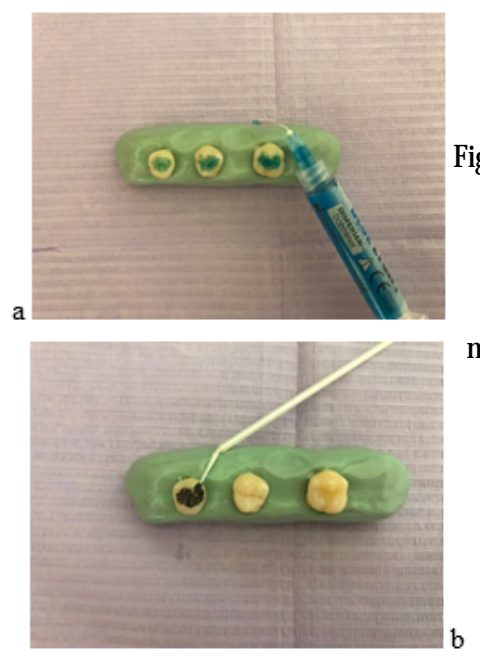

Fig.2. a) Demineralization of enamel surfaces with phosphoric acid $37 \%$; b) Application of dental adhesive loaded with magnetic nanoparticles on the enamel surfaces
For 5 samples, the magnetic nanoparticle loaded adhesive was applied by brush, air-blown and photopolymerized for $20 \mathrm{~s}$, and for the other 10 samples the adhesive was applied to the surface of the teeth in a magnetic field for 2 min for 5 samples and 5 min for the other 5 , being subsequently photopolymerized for $20 \mathrm{~s}$ ( fig 3a, fig 3b.) .

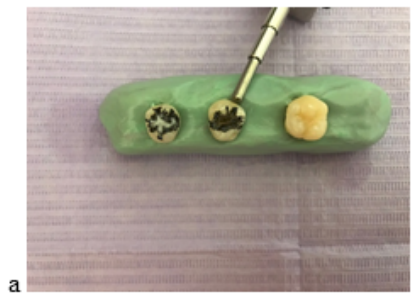

Fig.3. a) Magnetic field application on teeth, always in contact with the surfaces

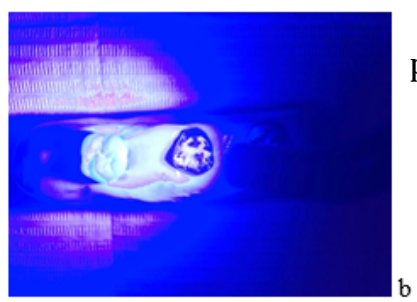

b) Adhesive photopolymerization for $20 \mathrm{~s}$

After the photopolymerization of the adhesive, resin based material was applied on teeth surfaces (fig.4.a., fig.4.b.).

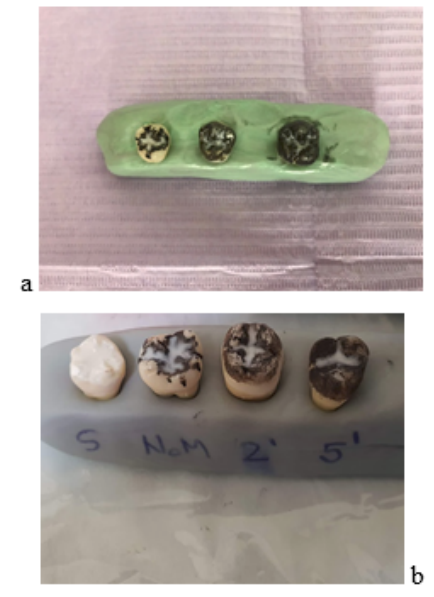

Fig.4. a, b) Samples view after resin based sealant application

All the samples were cut and analyzed by optical microscopy. The A377 Optical Microscope used up to 200x sizes, and the acquisition of larger images was achieved using a 2MPX acquisition sensor with a focus of up to $40 \mathrm{~mm}$. Data acquisition was made via the USB 2.0 port of the central computer. The surface brightness of the samples was generated using the 10 leds on the CMOS sensor edges (fig.5.a,b, fig.6.a,b)
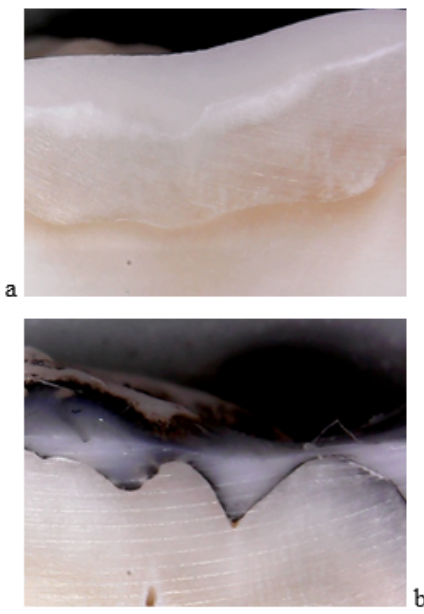

Fig.5. Optical analysis of the samples a) Adhesive layer without nanoparticles inclusion on sample probes b) Adhesive layer with nanoparticles insertion applied on teeth without magnetic field 

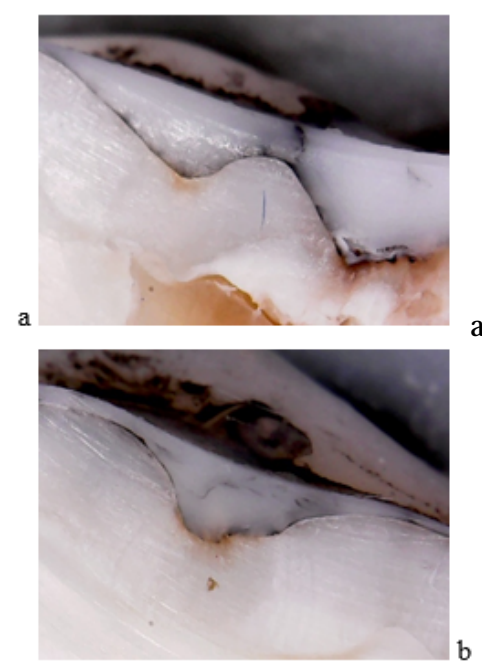

Fig.6. Optical analysis of the samples a) Adhesive layer applied on teeth in a magnetic field for 2 min b) Adhesive layer applied on teeth in a magnetic field for $5 \mathrm{~min}$

Adhesive layer measurements were made using the ImageJ software, by importing images and calibrating pixels according to the scale generated by the optical microscope.

\section{Results and discussions}

Application of adhesive on dental surfaces should improve the binding strength of the final adhesive restoration and should prevent dental sensitivity and bacterial contamination, by sealing the dentinal tubes.[19]

An important factor, besides the adhesion power, is also the thickness of the adhesive layer that can influence the adaptability of the applied materials over it [20].

The use of sealants over adhesives has a higher success rate at 6 months after application, than the use of sealants without the use of adhesive materials [21].

The presence of a layer of adhesive between the tooth and the sealing material for pits and fissures does not affect the success of the sealing procedure. When itis impossible to isolate the teeth and the saliva control is deficient, the quality of the seals can be increased by applying a layer of adhesive [22].

As a result of the measurements made, the thickness of the adhesive layer without nanoparticles ranged betw een $0.067 \mathrm{~mm}$ and $0.378 \mathrm{~mm}$ (fig.7, table 1).

The results of the sample measurements in which the adhesive was loaded with ferric nanoparticles generated thicknesses of the adhesive layer ranging from $0.018 \mathrm{~mm}$ to $0.112 \mathrm{~mm}$, its thickness decreasing by incorporating the nanoparticles into the adhesive mass (fig.8, table 2 ).

The adhesive loaded with magnetic nanoparticles and applied to the surface of the teeth in the magnetic field for 2 min generated adhesive layer thicknesses between 0.011 $\mathrm{mm}$ and $42 \mathrm{~mm}$. (fig.9, table 3)

\begin{tabular}{|c|c|c|l|l|l|c|}
\hline No. & \multicolumn{1}{l|}{ Area } & \multicolumn{1}{l|}{ Mean } & Min. & \multicolumn{1}{l|}{ Max } & \multicolumn{1}{l|}{ Angle } & Length (mm) \\
\hline 1 & 0.003 & 211.597 & 195.333 & 219.333 & -86.634 & 0.378 \\
\hline 2 & 0.002 & 202.071 & 187.667 & 208.561 & -91.302 & 0.326 \\
\hline 3 & 0.002 & 190.864 & 178.810 & 195.952 & -91.637 & 0.259 \\
\hline 4 & $8.762 \mathrm{E}-4$ & 187.274 & 183.267 & 188.733 & -93.814 & 0.111 \\
\hline 5 & $5.476 \mathrm{E}-4$ & 189.167 & 185.667 & 196.000 & -90.000 & 0.067 \\
\hline 6 & 0.001 & 186.834 & 180.680 & 195.333 & -85.426 & 0.186 \\
\hline 7 & 0.003 & 189.735 & 175.567 & 202.553 & -73.887 & 0.347 \\
\hline 8 & 0.002 & 193.521 & 177.423 & 203.788 & -67.479 & 0.328 \\
\hline 9 & 0.001 & 186.268 & 174.440 & 195.183 & -73.072 & 0.178 \\
\hline 10 & $8.214 \mathrm{E}-4$ & 201.220 & 192.214 & 208.000 & -65.225 & 0.106 \\
\hline
\end{tabular}

MATERIALE PLASTICE $\bullet 56$ No. $2 \bullet 2019$

http://www.revmaterialeplastice.ro

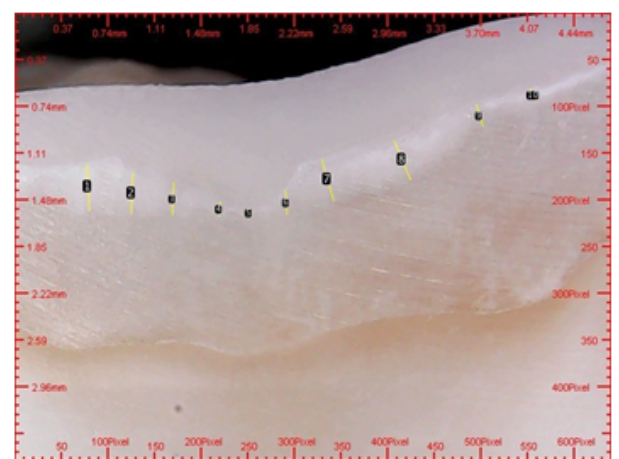

Fig.7 Optical microscopy measurements for dental probes with adhesive without magnetic nanoparticles reinforcement applied on teeth surfaces without magnetic field

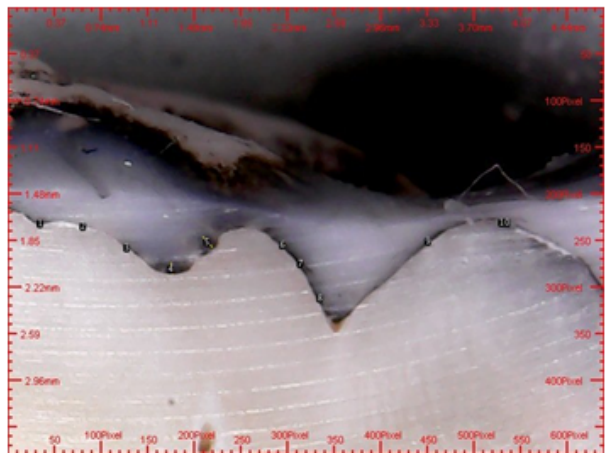

Fig.8 Optical microscopy measurements for dental probes with adhesive loaded with nanoparticles applied on teeth surfaces without magnetic field

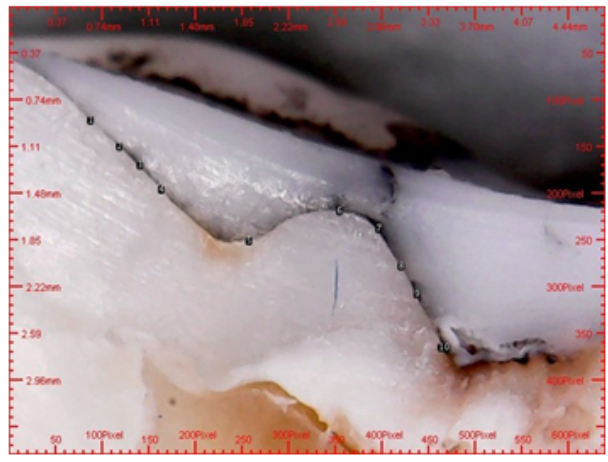

Fig.9 Optical microscopy measurements for dental samples with adhesive applied in a magnetic field for $2 \mathrm{~min}$

The thickness of the adhesive layer in the case of samples in which magnetic nanoparticles adhesive was applied to the surface of the teeth by means of a magnetic field for 5 min was further diminished, having values ranging from $0.011 \mathrm{~mm}$ to $0.028 \mathrm{~mm}$, observing an uniformity on the interface between the tooth and sealing material. (fig.10, table 4)

\section{Table 1}

AREAS OF INTEREST AND THICKNESS OF THE ADHESIVE LAYER FOR SAMPLES WHERE ADHESIVE WASN'T LOADED WITH MAGNETIC NANOPARTICLES 


\begin{tabular}{|c|l|l|l|l|l|l|}
\hline No. & Area & Mean & Min. & Max & Angle & Length (mm) \\
\hline 1 & $2.190 \mathrm{E}-4$ & 55.484 & 25.115 & 112.296 & -116.565 & 0.020 \\
\hline 2 & $1.643 \mathrm{E}-4$ & 169.062 & 146.000 & 201.185 & -116.565 & 0.018 \\
\hline 3 & $2.190 \mathrm{E}-4$ & 116.889 & 99.000 & 146.333 & -135.000 & 0.021 \\
\hline 4 & $7.119 \mathrm{E}-4$ & 59.245 & 3.519 & 117.667 & -85.236 & 0.089 \\
\hline 5 & $8.762 \mathrm{E}-4$ & 44.104 & 24.037 & 68.667 & -47.726 & 0.112 \\
\hline 6 & $3.286 \mathrm{E}-4$ & 48.923 & 27.674 & 80.333 & -149.036 & 0.040 \\
\hline 7 & $2.738 \mathrm{E}-4$ & 36.244 & 27.111 & 54.333 & -126.870 & 0.032 \\
\hline 8 & $2.738 \mathrm{E}-4$ & 54.400 & 43.222 & 72.667 & -153.435 & 0.031 \\
\hline 9 & $3.286 \mathrm{E}-4$ & 71.068 & 33.778 & 122.407 & -45.000 & 0.035 \\
\hline 10 & $2.190 \mathrm{E}-4$ & 120.599 & 101.000 & 137.370 & -108.435 & 0.020 \\
\hline
\end{tabular}

\begin{tabular}{|l|l|l|l|l|l|l|}
\hline \multicolumn{1}{l|l}{ No. } & Area & Mean & Min. & Max & Angle & Length (mm) \\
\hline 1 & $1.643 \mathrm{E}-4$ & 146.653 & 133.667 & 161.333 & 45.000 & 0.013 \\
\hline 2 & $1.643 \mathrm{E}-4$ & 124.000 & 113.000 & 137.000 & 26.565 & 0.017 \\
\hline 3 & $3.286 \mathrm{E}-4$ & 109.829 & 93.667 & 134.750 & 53.130 & 0.037 \\
\hline 4 & $1.643 \mathrm{E}-4$ & 139.181 & 129.708 & 156.667 & 45.000 & 0.016 \\
\hline 5 & $1.643 \mathrm{E}-4$ & 146.236 & 118.833 & 173.667 & 90.000 & 0.015 \\
\hline 6 & $2.738 \mathrm{E}-4$ & 63.754 & 42.458 & 104.500 & 90.000 & 0.030 \\
\hline 7 & $3.833 \mathrm{E}-4$ & 25.201 & 8.111 & 53.778 & 45.000 & 0.042 \\
\hline 8 & $1.095 \mathrm{E}-4$ & 90.611 & 72.222 & 109.000 & 26.565 & 0.011 \\
\hline 9 & $2.738 \mathrm{E}-4$ & 43.533 & 18.222 & 66.000 & 14.036 & 0.030 \\
\hline 10 & $3.286 \mathrm{E}-4$ & 14.894 & 2.467 & 50.185 & 36.870 & 0.039 \\
\hline
\end{tabular}

Table 2

AREAS OF INTEREST AND THICKNESS OF THE ADHESIVE LAYER FOR SAMPLES WHERE ADHESIVE WASLOADED WITH MAGNETIC NANOPARTICLES AND APPLIED ON TEETH WITHOUT MAGNETIC FIELD

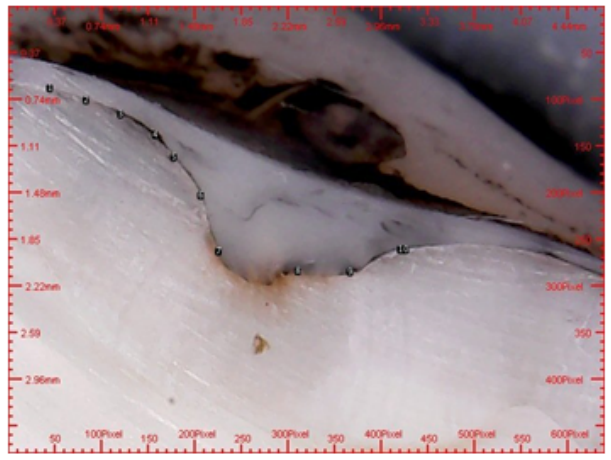

Fig.10 Optical microscopy measurements for dental probes with adhesive applied in a magnetic field for $5 \mathrm{~min}$

Table 3

AREAS OF INTEREST AND THICKNESS VALUES FOR SAMPLES WHERE ADHESIVE LOADED WITH NANOPARTICLESWAS APPLIED IN MAGNETIC FIELD FOR 2 min

\begin{tabular}{|c|l|l|l|l|l|l|}
\hline \multicolumn{1}{l|l}{ No. } & \multicolumn{1}{l|}{ Area } & Mean & \multicolumn{1}{l|}{ Min. } & Max & \multicolumn{1}{l|}{ Angle } & Length (mm) \\
\hline 1 & $1.095 \mathrm{E}-4$ & 162.074 & 156.593 & 167.556 & -135 & 0.011 \\
\hline 2 & $1.095 \mathrm{E}-4$ & 109.000 & 103.000 & 115.000 & -90 & 0.011 \\
\hline 3 & $2.738 \mathrm{E}-4$ & 75.974 & 56.093 & 94.556 & -123.690 & 0.027 \\
\hline 4 & $2.738 \mathrm{E}-4$ & 25.770 & 5.000 & 74.667 & -146.310 & 0.028 \\
\hline 5 & $1.095 \mathrm{E}-4$ & 77.778 & 77.000 & 78.556 & 180.000 & 0.010 \\
\hline 6 & $1.643 \mathrm{E}-4$ & 91.074 & 80.000 & 97.222 & 180.000 & 0.016 \\
\hline 7 & $1.643 \mathrm{E}-4$ & 89.926 & 82.778 & 94.333 & 180.000 & 0.015 \\
\hline 8 & $2.190 \mathrm{E}-4$ & 89.978 & 73.679 & 108.667 & -90.000 & 0.025 \\
\hline 9 & $2.190 \mathrm{E}-4$ & 54.000 & 29.333 & 87.000 & -90.000 & 0.020 \\
\hline 10 & $1.643 \mathrm{E}-4$ & 109.926 & 87.111 & 136.333 & -90.000 & 0.015 \\
\hline
\end{tabular}

Table 4

AREAS OF INTEREST AND THICKNESS VALUES FOR SAMPLESW HERE ADHESIVE WAS APPLIED IN MAGNETIC FIELD FOR 5 min

\section{Conclusions}

On the basis of the analyzes performed, the loading of the dental adhesive with magnetic nanoparticles and its application in the procedures of sealing the dental pits and fissures prior to the application of the resin sealing material leads to the decrease of the adhesive thickness layer.
Applying dental adhesive loaded with nanoparticles on the surface of the teeth by in a magnetic field also leads to a decrease in the thickness of the adhesive layer, but also to an surface uniformity of the adhesive, involving superior control of the materials used. 
Acknowledgement: This research was partially supported by the PhD grant of the Victor Babes University of Medicine and Pharmacy of Timisoara -3712/01.10.2015 (contractno.11521/01.10.2015).

\section{References}

1. BARBARA CVIKL, ANDREASMORITZ, KATRIN BEKES, Pit and Fissure Sealants - A comprehensive Review, Dentistry J ournal 2018, doi:10.3390/ dj6020018

2.BRUCE A. DYE, GINA THORNTON-EVANS, XIANFEN LI, TIMOTHY J. IAFOLLA, Dental Caries and Sealant Prevalence in Children and Adolescents in the United States, 2011-2012, NCHS Data Brief, No. 191, March 2015

3. YOUNG DA, NOVY BB, ZELLER GG, ET AL; American Dental Association Council on Scientific Affairs. The American Dental Association Caries Classification System for clinical practice: a report of the American Dental Association Council on Scientific Affairs [published correction appears in J Am Dent Assoc 2015;146(6):364365]. J Am Dent Assoc 2015;146(2):79-86.

4. TWETMAN S., FONTANA M, FEATHERSTONE JD, Risk assessment can we achieve consensus?, Community Dent Oral Epidemiol., 2013 Feb, 41(1):e64-70. doi: 10.1111/cdoe.12026

5. M. FONTANA, J.A. PLATT, G.J. ECKERT, C. GONZALEZ-CABEZAS, K. YODER, D.T. ZERO, M. ANDO, A.E. SOTO-ROJAS, M.C. PETERS, Monitoring os Sound and Carious Surfaces under Sealants over 44 Months, Journal of Dental Research, November 1 2014, Volume 93, Issue 11, page 1070-1075

6. FEIGAL, R.J .; DONLY, K.J., The use of pit and fissure sealants. Pediatr. Dent. 2006, 28, 143-150

7. HELENA FORSS, TANYA WALSH, ANNE NORDBLAD, MARJUKKA MÄKELÄ, HELEN V WORTHINGTON, AND ANNELI AHOVUO SALORANTA, Pit and Fissure sealants for preventing dental decay in permanent teeth, Cochrane Database Syst Rev., 2017 July, 10.1002/ 14651858.CD001830.pub5

8. HAZNEDAROĐLU E, GUNER S, DUMAN C, MENTES A. A 48- month randomized controlled trial of caries prevention effect of a one-time application of glass ionomer sealant versus resin sealant. Dent Mater J 2016;35(3):532-8.

9. R. CONDO, A. CIOFFI, A. RICCIO, M. TOTINO, S.G. CONDO, and L. CERRONI, Sealants in dentistry: a systematic review of the literature, Oral \& Implantology, 2014 apr 4, PMCID: PMC3982302

10. NICHOLSON, J.W. Polyacid-modified composite resins (compomers) and their use in clinical dentistry.Dent. Mater. 2007, 23, 615-622.

11. RUSE, N.D. What is a compomers? J. Can. Dent. Assoc. 1999, 65, 500-504.
12. WRIGHT JT, TAMPI MP, GRAHAM L, ET AL., Sealants for preventing and arresting pit-and-fissure occlusal caries in primary and permanent molars: a systematic review of randomized controlled trials-a report of the American Dental Association and the American Academy of Pediatric Dentistry. J Am Dent Assoc 2016;147(8):631-45.

13.*** AMERICAN ACADEMY OF PEDIATRIC DENTISTRY AND AMERICAN DENTAL ASSOCIATION, Use of Pit-and-Fissure Sealants, Recommendations:Clinical Practice Guide, 2016

14. MEHRABKHANI, M.; MAZHARI, F.; SADEGHI, S.; EBRAHIMI, M. Effects of sealant, viscosity, and bonding agents on microleakage of fissure sealants: An in vitro study. Eur. J. Dent. 2015, 9, 558-563.

15. KANTOVITZ KAMILA ROSAMILIA, MOREIRA KELLY MARIA SILVA, PASCON FERNANDA MIORI, NOCITI FRANCISCO HUMBERTO, MACHADO TABCHOURY CINTHIA P., PUPPIN-RONTANI REGINA MARIA, Penetration of Filled and Unfilled Resin Sealants on Different Enamel Substrates, Pediatric Dentistry, Volume 37, Number 7, 2016, pp. 472$476(5)$

16. ERBAS UNVERDI G, ATAC SA, CEHRELI ZC, Effectiveness of pit and fissure sealants bonded with different adhesive systems: a prospective randomized controlled trial, Clin Oral Investig. 2017 Sep;21 (7):2235-2243. doi: 10.1007/s00784-016-2016-8. Epub 2016 Nov 30. 17. MOLIN MK, KARLSSON SL, KRISTIANSEN MS. Influence of film thickness on joint bend strength of a ceramic/resin composite joint. Dent Mater. 1996;12:245-9

18. ANCHAL QANUNGO, MEENA AJAY ARAS, VIDYA CHITRE, ASHWIN MYSORE, BHAVYA AMIN, SOHIL RAIKUMAR DASWANI, Immediate dentin sealing for indirect bonded restorations, J urnal of Prosthodontic Research, 2016, p 240-249

19. MAGNE P, Immediate dentin sealing: a fundamental procedure for indirect bonded restorations. J Esthet Restor Dent 2005;17:144-54.

20. M. STAVRIDAKIS, I. KREJCI, P. MAGNE, Immediate Dentin Sealing of Onlay Preparations: Thickness of Pre-cured Dentin Bonding Agent and Effect of Surface Cleaning, Operative Dentistry, 2005, 30-6, 747757

21. BOKSMAN L, MCCONNELL RJ, CARSON B, MCCUTCHEON-J ONES EF. Two years clinical evaluation of two pit and fissure sealants placed with or without bonding agent. Quintessence Int 1993 Feb;24(2):131133

22. USHA MOHAN DAS, SUMA G, Bonding Agents in Pit and Fissure Sealants: A Review, International J ournal of Clinical Pediatric Dentistry, September-December 2009; 2(3):1-6

Manuscript received: 16.03 .2019 